\title{
Targeting the EGFR Pathway for Cancer Therapy
}

\author{
James B. Johnston ${ }^{1,2}$, Sri Navaratnam 1 , Marshall W. Pitz 1 , Jerry M. Maniate ${ }^{3}$, Emilia \\ Wiechec $^{6,7}$, Heinrich Baust ${ }^{8}$, Joel Gingerich ${ }^{1}$, Georgios P. Skliris ${ }^{2}$, Leigh C. Murphy ${ }^{2,4}$ and \\ Marek Los*,2,4,5
}

\begin{abstract}
${ }^{1}$ Department of Internal Medicine, ${ }^{2}$ Manitoba Institute of Cell Biology, ${ }^{3}$ Department of Medical Oncology and Hematology, CancerCare Manitoba, ${ }^{4}$ Department of Biochemistry and Medical Genetics, ${ }^{5}$ Manitoba Institute of Child's Health University of Manitoba, 675 McDermot Ave., Winnipeg, MB, R3E OV9, Canada, ${ }^{6}$ Department of Experimental and Clinical Radiobiology, Oncology Center, Maria Sklodowka-Curie Memorial Institute, Wybrzeze Armii Krajowej 15, PL-44100 Gliwice, Poland, ${ }^{7}$ Department of Human Genetics, University of Aarhus, DK-8000 C Aarhus, Denmark, ${ }^{8}$ Department of Radiooncology, University of Erlangen, Germany
\end{abstract}

\begin{abstract}
Clinical studies have shown that HER-2/Neu is over-expressed in up to one-third of patients with a variety of cancers, including B-cell acute lymphoblastic leukemia (B-ALL), breast cancer and lung cancer, and that these patients are frequently resistant to conventional chemo-therapies. Additionally, in most patients with multiple myeloma, the malignant cells over-express a number of epidermal growth factor receptors (EGFR)s and their ligands, HB-EGF and amphiregulin, thus this growth-factor family may be an important aspect in the patho-biology of this disease. These and other, related findings have provided the rationale for the targeting of the components of the EGFR signaling pathways for cancer therapy. Below we discuss various aspects of EGFR-targeted therapies mainly in hematologic malignancies, lung cancer and breast cancer. Beside novel therapeutic approaches, we also discuss specific side effects associated with the therapeutic inhibition of components of the EGFR-pathways. Alongside small inhibitors, such as Lapatinib (Tykerb, GW572016), Gefitinib (Iressa, ZD1839), and Erlotinib (Tarceva, OSI-774), a significant part of the review is also dedicated to therapeutic antibodies (e.g.: Trastuzumab / Herceptin, Pertuzumab / Omnitarg / rhuMab-2C4, Cetuximab / Erbitux / IMC-C225, Panitumumab / Abenix / ABX-EGF, and also ZD6474). In addition, we summarize, both current therapy development driven by antibody-based targeting of the EGFR-dependent signaling pathways, and furthermore, we provide a background on the history and the development of therapeutic antibodies.
\end{abstract}

Keywords: EGFR, cancer therapy, gefitinib, erlotinib, lapatinib, cetuximab, trastuzumab.

\section{INTRODUCTION}

The ErbB (HER) family of transmembrane tyrosine kinase (TK) type I receptors, plays an important role in processes such as cell growth, proliferation, survival, and differentiation. Members of the family include the HER1 (epidermal growth factor receptor, EGFR, ErbB1), HER2 (HER2/neu, ErbB2), HER3 (ErbB3) and HER4 (ErbB4). They contain an extracellular domain and an intracellular protein TK core and must form dimers to initiate signaling. Understanding the biological role of the HER family and advances in cancer therapy have led to the development of several therapeutic approaches including antibodies such as Trastuzumab (Herceptin ${ }^{\mathrm{TM}}$, Genentech, Inc., South San Francisco, CA), Pertuzumab (Omnitarg ${ }^{\mathrm{TM}}$, Genentech, Inc., South San Francisco, CA) formerly known as rhuMab-.2C4 that works by interfering with the interaction between singlechain HER-2 and other HER-family members, Cetuximab (Erbitux ${ }^{\mathrm{TM}}$, IMC-C225, ImClone Systems, Merck KgaA), Panitumumab (Abenix) formerly known as ABX-EGF, and also ZD6474 (Astrazeneca Pharmaceuticals, DE) a dual inhibitor that works by blocking the VEGF and EGF receptors [1].

*Address correspondence to this author at the Manitoba Institute of Cell Biology, ON6010-675 McDermot Ave. , University of Manitoba, Winnipeg, MB, R3E 0V9, Canada; Tel: +1-(204) 787-2294(office); -1403(lab) \&-4108(lab); Fax: +1-(204) 787-2190; E-mail: losmj@cc.umanitoba.ca
Beside therapeutic monoclonal antibodies, several 'small molecule'-inhibitors targeting the EGF-R signaling cascade are also currently being evaluated in clinical trials. They include compounds such as Lapatinib (Tykerb or GW572016, GlaxoSmithKline, Research Triangle Park, $\mathrm{NC}$ ), a reversible small-molecule inhibitor of ErbB1/ErbB2 tyrosine kinases, Gefitinib (Iressa ${ }^{\mathrm{TM}}$, ZD1839, Astrazeneca Pharmaceuticals, DE), and Erlotinib (Tarceva ${ }^{\mathrm{TM}}$, OSI-774, Genentech Inc. South San Francisco, CA) that target the HER1. The last two inhibitors work in a similar way, by blocking HER1 signaling, thereby inhibiting tumor growth and proliferation. Both, Erlotinib and Gefitinib, have been approved by the US Food and Drug Administration (FDA) for the treatment of patients with the most common form of lung cancer, Non-Small Cell Lung Cancer (NSCLC), and have also been evaluated in several other malignancies, with promising results.

\section{STRATEGIES FOR THE DEVELOPMENT OF THERAPEUTIC ANTIBODIES}

'Small-molecule' inhibitors are usually discovered by screening large chemical libraries, containing usually hundreds of thousands of compounds. In contrast, antibodybased drugs are developed by immunization with the molecule that should be selectively targeted. The target may be a growth receptor that under pathologic conditions (for example: EGF-receptor family) sustains the survival and 
proliferation of cancer cells, or for example, a mutated form of a naturally occurring molecule. While for practical reasons, the antibodies are usually being developed in mice, they cannot be efficiently used for therapy in humans due to their immunogenicity (they are recognized as "foreign" by the human immune system). Furthermore, antibody structure also has a profound effect on tumor targeting. Immunoglobulin belonging to the class " $\mathrm{G}$ " $(\mathrm{IgG})$ is the most commonly used class of antibodies. IgG, although one of the smallest of naturally occurring immunoglobulins, is still a rather large protein (approximately $150 \mathrm{kDa}$ ). Thus, it has slower distribution kinetics and limited tissue penetration as compared to small molecules. Larger antibodies, for example IgM, are usually not chosen for therapy. Several approaches are being taken to overcome these problems, and thus therapeutic antibodies come in "different forms and different sizes" [2].

Attempts to use antibody-based therapies began in the 1950 's and relied on polyclonal antibody preparations. Limited success was mainly due to the inherent problems associated with polyclonal antisera. The approach however gained feasibility in the mid-70s when Kohler and Milstein developed the methodology that allowed the manufacture of unlimited quantities of identical (monoclonal) antibodies (mAb, antibodies directed against specific antigens, produced by hybrid cells, "hybridomas", derived from the fusion between specific plasma cells [guarantees specificity] and myeloma cells [guarantees immortal growth]) [3]. Initially, murine, rabbit and rat antibodies were studied; however, they had several associated problems since they acted as immunogens for the human immune system. The immune response against such therapeutic antibodies quite often caused adverse effects such as "serum-sickness" and anaphylaxis. In addition, due to cross-species incompatibilities these antibodies were sometimes unable to stimulate cytotoxic humoral- or cellular immune responses such as Complement-mediated Cytotoxicity (CDC) or Antibody Dependent Cellular Cytotoxicity (ADCC), which are necessary to destroy malignant cells. In order to overcome this problem, chimeric or "hybrid antibodies" were constructed by linking human antibody backbone regions with murine or primate variable regions. More advanced versions of these antibodies were developed and today are known as the "humanized antibodies" (human framework Ig containing only rodent sequences encoding the three complementarity determining regions are also called "variable regions"). These antibodies activate immune responses (both $\mathrm{CDC}$ and $\mathrm{ADCC}$ ) and show better performance in clinical trials [4].

\section{ADVANCES IN THE DEVELOPMENT OF THERAPEUTIC ANTIBODIES}

Efforts have been made to further improve the cytotoxic activity of therapeutic monoclonal antibodies. For example, co-administration of -glucan as an adjuvant with therapeutic monoclonal antibodies markedly enhances the recruitment of the components of the complement lytic cascade, and thus improves their CDC- or ADCC activity. -glucan primes leukocyte complement receptor 3 (CR3) for enhanced cytotoxicity against iC3b opsonized tumor cells [5]. For example: Herceptin (Trastuzumab), Rituxan (Rituximab,
Mabthera) and Erbitux (Cetuximab) promote tumor regression by enhancing leukocyte-mediated killing of tumor cells coated with the iC $3 b$ [5]. Combinations of $\mathrm{mAb}$ and -glucan have been shown to significantly increase tumor regression in: chronic lymphocytic leukemias, small lymphocytic lymphoma, childhood Hodgkin's lymphoma, childhood Non-Hodgkin's lymphoma, other leukemias and lymphomas, neuroblastoma, breast and liver tumors (see: http://www.clinicaltrials.gov/ for a detailed list).

So-called "Single Chain" antibody fragments (scFv), the ultimate simplification of antibody molecules have been engineered mainly in bacteria. $\mathrm{scFv}$ can be designed to form dimers and trimers by varying the length of their polypeptide linkers. An $\mathrm{scFv}$ fragment with a linker length of 3-12 residues cannot fold into a functional Fv domain, and therefore associates with another $\mathrm{scFv}$ molecule to form a bivalent dimer. Trimers and tetramers can be formed by further reducing the linker's length. These molecules have the advantage of increased tumor penetration and faster clearance rates than the parental Ig due to their smaller size. Designing therapeutic antibodies to include the $\mathrm{Fc}$ domain prolongs serum half-life and complement-mediated effects. In addition, antibody fragments can be fused with a wide variety of molecules to alter functionality or to introduce a secondary activity, such as: radioisotopes for cancer imaging, enzymes for pro-drug therapy, or lipids for improved systemic delivery [6].

Antibodies may also be chemically modified. For example, bi-specific antibodies are formed through the association of two different $\mathrm{scFv}$ molecules that each contain a VH and VL domain (variable regions from both heavy and light chain) from different parent Igs. The bi-specific antibodies usually recognize two different antigens, thus they are able to cross-link different target antigens either on the same cell or on two different cells. As a result, they efficiently recruit cytotoxic T cells to their target cancer cells or effectively activate CDC.

Direct arming of antibodies is a strategy to enhance the effectiveness of anti-tumor antibodies. This is accomplished by covalently linking antibodies to molecules or proteins that are used to destroy tumor cells such as: radionuclides, toxins, or cytokines. The latter stimulates the anti-tumor immune response without the toxicity associated with systemic cytokine delivery. Antibodies can also be armed indirectly by attaching engineered antibody fragments to the surface of liposomes loaded with drugs or toxins for tumorspecific delivery [7]. For example, in preclinical studies, anti-HER2 scFv immunoliposomes containing doxorubicin showed increased retention in the circulation and improved efficiency compared to free doxorubicin, non-antibody conjugated liposomal doxorubicin, and the anti-HER2 monoclonal antibody Trastuzumab [2, 8]. As another example, Gemtuzumab ozogamicin (MylotargTM) is a humanized anti-CD33 monoclonal antibody covalently linked to the cytotoxin calicheamicin. CD33 is expressed on early myeloid cells as well as leukemic blast cells, but is rarely expressed outside the hematopoietic system. This makes it an attractive target for use in therapy. Gemtuzumab ozogamicin binding to CD33 leads to endocytosis, followed by cleavage of the covalent linkage between the antibody and calicheamicin inside the lysosomes. The calicheamicin is 
released and it induces sequence specific cleavage of doublestranded DNA [9].

Antibodies may also be labeled with a radionuclide either for diagnostic- or for therapeutic purposes. Thus, the antibodies may serve as vectors targeting tumor antigens, for example, radioactive anti-carcinoembryonic antigen antibodies are used in the treatment of colorectal cancer. This strategy works through the accumulation of high energy $\beta$ particles (that have a short penetration depth) within the tumor which is emitted from a radionuclide $\left({ }^{131} \mathrm{I},{ }^{90} \mathrm{Yt}\right.$, $\left.{ }^{111} \mathrm{In}\right)$. Using this method in conjunction with a $\gamma$-detector also makes it possible to locate and stage tumors [10]. Recently, the first radioimmunoconjugate was approved for treating non-Hodgkin's lymphoma. Zevalin (ibritumomab, tiuxetan) is a ${ }^{90} \mathrm{Yt}$ labeled anti-CD20 monoclonal antibody that incorporates $\beta$-emitting radioisotopes [11]. Below we focus on therapies that target the EGF-receptor pathway on various types on malignancies.

\section{TARGETING OF THE EGFR PATHWAY IN HEMATOLOGICAL MALIGNANCIES}

Despite the extensive amount of research devoted to targeting the epidermal growth factor receptor (EGFR) pathway as a treatment for solid tumors, less is known about this pathway in the hematological malignancies [12]. While HER-2/Neu (ErbB2) is highly expressed in epithelial cells, HER-2/Neu mRNA is only detected at low levels in normal peripheral blood mononuclear cells, bone marrow cells and in leukemic blasts [13]. Within these cell types, HER-2/neu surface protein expression is only found in B cell acute lymphoblastic leukemia (B-ALL), being detected in up to one-third (12 of 36) of patients [13, 14]. The incidence of HER-2/Neu positivity in B-ALL appears to correlate with patient age, occurring in $3.4 \%$ of children and $31 \%$ of adults $[13,14]$. This over-expression is not related to gene amplification, but may be related to transcriptional activation or post-translational modifications [14]. Moreover, patients with HER-2/Neu positivity are drugresistant suggesting that this may be a useful prognostic marker in B-ALL [14]. HER-2/neu specific cytotoxic T lymphocytes have been generated in vitro using peptidepulsed dendritic cells, and these cytotoxic $\mathrm{T}$ cells can lyse B-ALL cells expressing HER-2/Neu [15]. These data suggest that HER-2/Neu may be a target for treatment in B-ALL and that vaccination might be a useful approach for therapy [14]. Ongoing clinical studies are evaluating Trastuzumab (Herceptin $^{\mathrm{TM}}$ ) in B-ALL [14].

In contrast to ALL, HER-2/neu protein is not detected in Hodgkin's disease, non-Hodgkin's lymphoma, acute myeloid leukemia (AML), chronic lymphocytic leukemia and stable chronic myeloid leukemia (CML) [13, 16-18]. However, HER-2/Neu is expressed in CML where there is evidence of B-lymphoblastic crisis [12, 16-18]. Interestingly, although HER-2/Neu protein is not detectable in AML blasts, the EGFR kinase inhibitor, Gefitinib $\left(\right.$ Iressa $\left.^{\mathrm{TM}}\right)$, promotes the differentiation of AML cell lines and primary AML blasts in vitro [19]. Although the mechanism for this action is unknown, it is speculated that Gefitinib acts in AML through an EGFR-independent pathway.
In addition, to the importance of HER-2/Neu in ALL, there is a growing body of literature surrounding the EGFR and multiple myeloma [20-24]. Mahtouk et al. [24] found HER-2/Neu mRNA to be expressed in 9 myeloma cell lines, while ErbB1, ErbB3 and ErbB4 were only expressed in 3, 6 and 4 of these lines, respectively. Similarly, Otsuki et al. [22] found plasma cell lines to have increased levels of mRNA for HER-2/Neu, ErbB3 and ErbB4, while only the protein levels of HER-2/Neu were highly expressed. Primary myeloma cells appear to universally express ErbB1 or ErbB4 mRNA [24], and by immuno-histochemistry $12.9 \%$ of cases show HER-2/Neu expression [20]. Activation of these receptors appears to be important in the pathogenesis of myeloma as an antibody against HER-2/Neu inhibits the growth of myeloma cell lines [22]. This effect is associated with a slight accumulation of cells at G0/G1 and the upregulation of p21 expression [22]. More recently it has been demonstrated that the epidermal growth factor members, amphiregulin and heparin-binding epidermal growth factor-like growth factor (HB-EGF), are important in multiple myeloma [20, 21, 23, 24]. HB-EGF is present in a membrane and free form and both bind to ErbB1 and ErbB4 while amphiregulin binds to ErbB1 [24]. CD9 is also found on myeloma cell lines, and functions as a co-receptor for HB-EGF, increasing the activity of HB-EGF thirty-fold. HB-EGF is produced by plasma cell lines and cooperates with IL-6 to maintain cell viability [21]. In contrast, HBEGF is not secreted by primary myeloma cells but may in vivo be produced by other bone marrow cells, such as monocytes [24]. HB-EGF triggers the PI-3K/AKT pathway and the effect is blocked by a pan-ERbB kinase inhibitor [24]. A recent study has demonstrated that primary myeloma cells, but not normal plasma cells, express amphiregulin mRNA and that amphiregulin causes marrow stromal cells to produce IL-6, a cytokine implicated in multiple myeloma [23]. Moreover, amphiregulin also promotes the growth of primary myeloma cells [23]. The importance of HB-EGF and amphiregulin as growth factors in multiple myeloma has been confirmed by the finding that the pan-ErbB kinase inhibitor, PD169540, induced apoptosis in 10/14 primary myeloma cell lines and the ErbB1-specific inhibitor, Gefitinib, induced apoptosis in $4 / 14$ cases [23, 24]. In addition, a synergistic antitumor effect was seen between these agents and dexamethasone or an anti-IL6 antibody [23, 24]. Importantly, PD169540, Gefitinib, dexamethasone and anti-IL6 antibody did not affect the viability of other marrow cells $[23,24]$. These results indicate that inhibition of the EGFR pathway may be useful in the treatment of multiple myeloma.

\section{CLINICAL ADVANCES IN TARGETING EGFR PATHWAY IN LUNG CANCER}

Lung cancer is the leading cause of cancer-related mortality worldwide. Despite the advances in chemotherapeutic options for $80 \%$ of the lung cancer patients who are diagnosed with non-small cell lung cancer (NSCLC), the 5-year survival has been a dismal 15\% [25]. NSCLC frequently expresses the epidermal growth factor receptor (EGFR) and as a result, there has been considerable interest in carrying out clinical trials of EGFR targeting agents in NSCLC [26, 27] The EGFR- tyrosine kinase 
inhibitors (TKIs), namely Gefitinib (Iressa®; AstraZeneca) and Erlotinib (Tarceva®; OSI Pharma) are extensively studied in NSCLC and are currently incorporated into clinical practice.

\section{EGFR-Tyrosine Kinase Inhibitors (TKIs)}

\section{Gefitinib}

Two randomized, double blind, multi centre Phase II trials, IDEAL-1 (Iressa Dose Evaluation in Advanced Lung Cancer) and IDEAL-2 (Table 1), evaluated the efficacy of Gefitinib $250 \mathrm{mg}$ or $500 \mathrm{mg}$ per day orally as a single agent in advanced NSCLC patients who have failed one or two chemotherapy regimens [28, 29]. The primary end-points of the studies were objective tumor response rate (ORR) and disease related symptom improvement measured by LCS (lung cancer sub-scale). ORR of $8-19 \%$ and a median survival between 6 to 7 months, with tolerable toxicity, were reported in both studies and $35-43 \%$ of patients showed symptom improvement. As the $250 \mathrm{mg}$ per day dosage provided equivalent benefit but lower toxicity than $500 \mathrm{mg}$ per day, it was chosen as the dosage for Phase III investigations. A recently published large European phase III randomized study evaluated Gefitinib in 1692 patients who had undergone previous platinum-based chemotherapy [30]. Unfortunately, there was no survival benefit for Gefitinib in the overall study population (median survival $5.6 \mathrm{vs}$. 5.1 months; HR $=0.89 ; \mathrm{p}=0.11)$. However, Gefitinib was noted to provide a statistically significant survival benefit in patients of Asian origin and in never-smokers.

\section{Erlotinib}

A large Canadian-led international study compared Erlotinib $150 \mathrm{mg}$ per day, a TKI with placebo in patients with advanced NSCLC after failure of standard first or second-line chemotherapy [31]. This randomized, doubleblind trial of 731 patients noted a statistically significant difference for Erlotinib over placebo with response rate $(8.9 \%$ vs. $<1 \%$; p < 0.001$)$, progression-free survival $(2.2$ months vs. 1.8 months; $\mathrm{HR}=0.61 ; \mathrm{p}<0.001)$ and overall survival (6.7 months vs. 4.7 months; HR $=0.70 ; \mathrm{p}<$ 0.001), all in favor of Erlotinib. Response to Erlotinib was noted to be higher among Asians $(\mathrm{p}=0.02)$, women $(\mathrm{p}=$ 0.006), patients with adenocarcinoma $(\mathrm{p}<0.001)$ and lifetime non-smokers $(\mathrm{p}<0.001)$.

Apart from the above clinical factors, many earlier studies have also suggested that mutation in the region of the tyrosine kinase domain of EGFR predicts response to TKIs [32-34]. However, this was not observed when mutation was studied in a sub-group of patients in the above study. The EGFR expression and increased number of copies of EGFR were associated with increased responsiveness to Erlotinib but the mutation of EGFR did not correlate. None of these three tests were associated with increased survival [35]. Therefore, this test cannot be recommended as a prerequisite for selection of patients for therapy. It is difficult to understand why one phase III study using an EGFR-TKI would have improved survival while the other did not. This difference in results may be attributed to the under dosing of Gefitinib.

\section{EGFR_TKIs - Combined with Chemotherapy}

Gefitinib has also been investigated as part of first-line regimens for patients with advanced NSCLC. INTACT (Iressa NSCLC Trial Assessing Combination Treatment) 1 and INTACT 2 combined Gefitinib 250 or $500 \mathrm{mg}$ per day with cisplatin plus gemcitabine or carboplatin plus paclitaxel, (Table 1) [36, 37]. Non-significant differences

Table 1. Recent Clinical Trials that Involved Tyrosine Kinase Inhibitors in Lung Cancer

\begin{tabular}{|c|c|c|c|c|}
\hline & & Trial / Reference & Design (No. of Pts) & Survival / Outcomes \\
\hline \multirow[t]{5}{*}{ Gefitinib } & $250 \mathrm{vs} 500 \mathrm{mg}$ & $\begin{array}{l}\text { IDEAL } 1 \\
\text { [28] }\end{array}$ & $\begin{array}{c}\text { Phase II (200 pts) } \\
1 \text { or } 2 \text { prior platinum regimens }\end{array}$ & Symptom improvement \\
\hline & 250 vs $500 \mathrm{mg}$ & $\begin{array}{l}\text { IDEAL } 2 \\
{[29]}\end{array}$ & $\begin{array}{c}\text { Phase II }(216 \mathrm{pts}) \\
\geq 2 \text { Prior platinum \& docetaxel } \\
\text { regimens }\end{array}$ & Symptom improvement \\
\hline & $250 \mathrm{mg} v s$ placebo & $\begin{array}{l}\text { ISEL } \\
{[30]}\end{array}$ & $\begin{array}{l}\text { Phase III (1692 pts) } \\
\text { Intolerant or progression to } \\
\text { chemotherapy }\end{array}$ & $\begin{array}{c}\text { No overall survival benefit } \\
\text { Increased median survival in never-smokers } \\
\text { and Asians }\end{array}$ \\
\hline & $\begin{array}{c}\text { Cisplatin/gemcitabine } \pm \\
\text { Gefitinib }\end{array}$ & $\begin{array}{c}\text { INTACT } 1 \\
{[36]}\end{array}$ & $\begin{array}{l}\text { Phase III (1093 pts) } \\
1^{\text {st }} \text { line }\end{array}$ & No overall survival benefit \\
\hline & $\begin{array}{l}\text { Carboplatin/paclitaxel } \\
\pm \text { Gefitinib }\end{array}$ & $\begin{array}{c}\text { INTACT } 2 \\
{[37]}\end{array}$ & $\begin{array}{c}\text { Phase III (1037 pts) } \\
1^{\text {st }} \text { line }\end{array}$ & No overall survival benefit \\
\hline \multirow[t]{3}{*}{ Erlotinib } & $150 \mathrm{mg} v s$ placebo & $\begin{array}{c}\text { NCIC-CTG BR.21 } \\
{[31]}\end{array}$ & $\begin{array}{l}\text { Phase III ( } 731 \mathrm{pts}) \\
1 \text { or } 2 \text { prior chemotherapy } \\
\text { regimens }\end{array}$ & Significant improvement in overall survival \\
\hline & $\begin{array}{c}\text { Cisplatin/gemcitabine } \pm \\
\text { Erlotinib }\end{array}$ & $\begin{array}{c}\text { TALENT } \\
\text { J Clin Oncol 22(14S): } \\
\text { 7010, } 2004\end{array}$ & $\begin{array}{l}\text { Phase III (1172 pts) } \\
1^{\text {st }} \text { line }\end{array}$ & No overall survival benefit \\
\hline & $\begin{array}{c}\text { Carboplatin/paclitaxel } \\
\pm \text { Erlotinib }\end{array}$ & $\begin{array}{c}\text { TRIBUTE } \\
{[39]}\end{array}$ & $\begin{array}{l}\text { Phase III (1079 pts) } \\
1^{\text {st }} \text { line }\end{array}$ & No overall survival benefit \\
\hline
\end{tabular}


were noted for response rate or survival with the addition of Gefitinib. While no benefit was noted in the overall population, again there was a trend toward increased survival in patients with adenocarcinoma.

Erlotinib has also been combined with standard first-line chemotherapy regimens in patients with advanced NSCLC. The TALENT study (Table 1) included 1172 'chemo-naive' (previously not treated) patients who were to receive Erlotinib $150 \mathrm{mg}$ per day or placebo concurrently with six cycles of gemcitabine and cisplatin followed by monotherapy until disease progression [1, 38] Similar to Gefitinb, the addition of Erlotinib to chemotherapy provided no statistically significant differences in clinical outcomes. Likewise, the recently published TRIBUTE study (Table 1), a phase III trial combined carboplatin and paclitaxel chemotherapy with Erlotinib in 1079 patients demonstrated no difference in median survival [39]. In subset analysis, never-smokers experienced improved overall survival (OS) with Erlotinib (22.5 months vs. 10.1 months; HR =0.49), which was independent of tumor histology. Efforts are ongoing to combine other targeting agents (Vascular endothelial growth factor receptor antagonist) with TKIs and study their benefit in earlier stages of disease after radical treatment.

\section{Anti-EGFR Receptor Antibodies}

\section{Cetuximab}

a monoclonal antibody, is in clinical development [40]. To date, no randomized phase III studies in NSCLC have been published. When Cetuximab is added to docetaxel for recurrent NSCLC, a partial response rate of $28 \%$ and a stable disease rate of $17 \%$ were seen in a phase II study of 47 patients [41]. Encouraging results have been seen in Phase II studies combining Cetuximab with standard first-line treatment for chemo-naive metastatic NSCLC patients [42, 43]. These phase II results are intriguing because minimal toxicities were seen in combination compared to standard cytotoxic agents. Perhaps it will only be a matter of time before monoclonal antibody agents such as Cetuximab are used more extensively in the treatment of NSCLC. However, this will be dependent on the results of ongoing phase III studies.

\section{EGFR-TARGETING IN BREAST CANCER THERAPY}

Results from a recently completed phase II randomized trial in breast cancer, showed that patients who were given both Gefitinib (HER1-TK inhibitors, see Table 2) and an aromatase inhibitor (Arimidex, Astrazeneca Pharmaceuticals, DE) had a greater reduction in tumor Ki67 (proliferation) index, than patients assigned Gefitinib alone [44] (Table 3). However, other clinical trial data where Gefitinib was administrated alone to advanced breast cancer patients showed that it did not reduce the Ki67 index in tumors [45], and when Gefitinib was evaluated in 58 metastatic cancer patients pretreated with taxane and anthracycline, the treatment was well tolerated but not effective [46]. Currently Gefitinib is being evaluated in combination with other drugs to treat metastatic breast cancer in more than 20 studies (www.clinicaltrials.com).

Early trials for Erlotinib (TarcevaTM, OSI-774, Genentech, Inc., South San Francisco, CA), looked promising, but a subsequent phase II study was disappointing (02-C-0061; Table 3). Erlotinib is a small molecule TK inhibitor, which was co-developed by OSI Pharmaceuticals and Roche and also targets the HER1 receptor. Currently, Erlotinib is being tested either alone or in combination with other agents in 9 different trials in the setting of recurrent breast cancer (www.clinicaltrials.gov).

In contrast, Lapatinib (Tykerb or GW572016, GlaxoSmithKline, Research Triangle Park, NC), differs from the previous two compounds, in that it is a dual inhibitor of both HER1 and HER2 activity (Table 2). Results from a completed phase I trial (EGF10004, designed to evaluate the safety and clinical activity) in 67 patients with metastatic tumors showed that the drug was well tolerated and prolonged stable disease in some patients [47]. Interim results of a phase II trial (EGF20009), where Lapatinib is being evaluated as first-line therapy for HER2 patients not been treated with Trastuzumab, showed a $35 \%$ response rate (reported May 2005 at the annual meeting of the American Society of Clinical Oncology). Lapatinib has since entered phase II/III trials in patients with advanced breast cancer. For example, Lapatinib is being evaluated alone in a trial conducted at the Baylor Breast Care Center, while in another study, initiated in April of 2005, Lapatinib's safety is being investigated in combination with Paclitaxel in treating inflammatory breast cancer patients.

Trastuzumab (Herceptin) is one of the first molecularbased targeted treatments for metastatic breast cancer. It selectively binds with high affinity to the extracellular domain of the HER2 receptor and inhibits cancer cells carrying excessive amounts of the HER2 gene. Trastuzumab may be used alone or combined with a chemotherapeutic agent. In 2001 the results of a phase III trial were published,

Table 2. Current Drugs for Targeted Therapy of Breast Cancer Developed Against EGF Receptors

\begin{tabular}{|c|c|c|}
\hline Receptor Name & Abbreviations & Current Drugs \\
\hline \hline \begin{tabular}{c|c} 
Epidermal Growth \\
Factor Receptor
\end{tabular} & $\begin{array}{c}\text { EGFR or HER1 } \\
\text { or ErbB1 }\end{array}$ & $\begin{array}{c}\text { Gefitinib (Iressa } \\
\text { EM }, \text { ZD183inib (Tarceva } \\
\text { EM }) \\
\text { Lapatinib (Tykerb, GW572016) } \\
\text { Pertuzumab (Omnitarg } \\
\text { ZD })\end{array}$ \\
\hline Epidermal Growth & & $\begin{array}{c}\text { Trastuzumab (Herceptin) } \\
\text { Pertuzumab (Omnitarg }\end{array}$ \\
Factor Receptor 2 & Lapatinib (Tykerb, GW572016) \\
\hline
\end{tabular}


Table 3. Summary of Completed Clinical Trials for HER Targeted Agents for Treating Breast Cancer

\begin{tabular}{|c|c|c|c|}
\hline Drug Name & $\begin{array}{l}\text { Clinical Trial } \\
\text { Number /Phase }\end{array}$ & Report Summary & References \\
\hline Gefitinib & $\begin{array}{l}\text { Phase II } \\
\text { Phase II } \\
\text { Phase II }\end{array}$ & $\begin{array}{c}\text { Single agent and combined therapy were tolerated and effective } \\
\text { Lack of significant clinical activity } \\
\text { Drug was tolerated but not effective }\end{array}$ & $\begin{array}{l}{[44]} \\
{[45]} \\
{[85]}\end{array}$ \\
\hline Erlotinib & 02-C-0061 (Phase II) & No effect & www.clinicaltrials.gov \\
\hline Lapatinib & $\begin{array}{l}\text { EGF10004 (Phase I) } \\
\text { EGF20009 (Phase II) }\end{array}$ & $\begin{array}{l}\text { Prolonged stable disease } \\
\text { Showed } 35 \% \text { response rate }\end{array}$ & $\begin{array}{l}{[47]} \\
\text { Interim results in } 2005\end{array}$ \\
\hline Trastuzumab & $\begin{array}{c}\text { Phase III } \\
\text { NCT00045032 (Phase III) } \\
\text { NCT } 00004067 \\
\& \text { NCT } 00005970 \\
\text { Phase II } \\
\text { Phase II }\end{array}$ & $\begin{array}{c}\text { Showed 25\% improvement in survival and increased the clinical } \\
\text { benefit }\end{array}$ & $\begin{array}{l}{[48]} \\
{[49]} \\
{[50]} \\
\\
{[51]} \\
\\
{[52]}\end{array}$ \\
\hline Pertuzumab & Phase I & Clinically active and well tolerated & {$[53]$} \\
\hline ZD6474 & Phase II & $\begin{array}{l}\text { Drug monotherapy was well tolerated but showed limited } \\
\text { clinical activity }\end{array}$ & {$[54]$} \\
\hline
\end{tabular}

reporting a $25 \%$ improvement in survival in those patients treated with Trastuzumab plus chemotherapy, compared with those treated with chemotherapy alone [48] (Table 3). Since then Trastuzumab has been and is currently being evaluated in 112 trials in combination with numerous other chemotherapeutic and hormonal therapy agents (www.clinicaltrials.gov.). Recently, first year results were published from a multicenter trial, showing that Trastuzumab significantly improved disease-free survival among women with HER2-positive cancers who had received adjuvant and neoadjuvant chemotherapy [49]. The combined interim results of two other trials comparing adjuvant chemotherapy with or without Trastuzumab also showed that the addition of Trastuzumab significantly improved outcome among patients with surgically removed HER2 positive breast cancer (for review see [50]). Trastuzumab together with chemotherapy in a neoadjuvant setting also increased pathologic complete response in HER2-positive patients [51] (Table 3). Furthermore, other clinical trials data showed that Trastuzumab combined with docetaxel was superior to docetaxel alone in terms of overall survival and response rate for patients with HER2 positive metastatic breast cancer [52] (Table 3).

Pertuzumab (Omnitarg ${ }^{\mathrm{TM}}$, Genentech, Inc., South San Francisco, CA) formerly known as rhuMab-2C4, is also a recombinant humanized monoclonal antibody, which binds to the extracellular domain II of the HER2 receptor and blocks the interaction between HER2 with other HER family members (Table 2). It is the first in a new class of agents known as HER dimerization inhibitors. Results reported from a phase I study of Pertuzumab in 21 patients with advanced recurrent breast cancer, showed that the drug was well tolerated and clinically active, suggesting that inhibition of dimerization may be a potentially attractive therapy approach [53]. Currently Pertuzumab is in phase II trial testing its combination with Trastuzumab in patients with locally advanced and metastatic HER-2 over-expression breast cancer (trial 06-C-0035, Table 3).
Last but not least, ZD6474 (Astrazeneca Pharmaceuticals, DE) a dual inhibitor that works by blocking the VEGF and EGF receptors is also currently being evaluated in clinical trials. Results reported from a completed phase I study, show that ZD6474 was well tolerated but showed limited clinical activity in 44 patients treated previously for metastatic cancer with an anthracycline and taxane [54] (Table 3). Thus, biological therapies targeting the HER family members appear to be efficacious in advanced breast cancer treatment.

\section{SIDE EFFECTS OF AGENTS THAT TARGET THE EGFR/HER PATHWAY}

The side effect profile of targeted agents directed against the EGFR/HER-2 pathways have reproducible and unique toxicities different from conventional chemotherapeutic drugs (Table 4) [55]. In general, EGFR/HER-2 targeted therapies are well tolerated and require infrequent dose interruptions or dose reductions, (see below) [28, 31].

Skin rash is a classic adverse effect of targeted therapy. It has been described for both monoclonal antibodies and small molecule receptor tyrosine kinase inhibitors directed against the EGFR pathway [28, 31, 36, 37, 39, 56]. The most common skin eruption seen, an acneform rash, consists of erythematous follicular papules and pustules that may form yellow crusts [57]. The rash is confined to areas of the skin full of sebaceous glands and includes the face, neck, retroauricular area, shoulders, upper trunk and scalp. The palms and soles are typically spared [58]. This rash can be distinguished from true acne by the absence of comedones (blackheads or whiteheads) and from other acneform drug eruptions by the presence of pruritus [58]. The rash typically begins after a few days of therapy and reaches a maximum by 2-3 weeks. [58] While grade 3-4 skin rash is uncommon, seen in $1-9 \%$ of patients, all grades of skin rash have been reported to occur in $26.2-80 \%$ of patients [28, 31, 36, 37, 
Table 4. Grade $\geq 3$ Toxicity for Targeted Agents in Selected Phase II and III Trials

\begin{tabular}{|c|c|c|c|c|c|c|c|}
\hline Drug & Type & Site & Rash & Diarrhea & Nausea and vomiting & Asthenia & Hypersensitivity reaction \\
\hline & & & \multicolumn{5}{|c|}{ Grade $\geq 3$, Expressed as $\%$} \\
\hline Cetuximab [56] & $\mathrm{mAb}$ & Colon & 5.2 & 1.7 & 4.3 & 10.4 & 3.5 \\
\hline Gefitinib [28] & TKIs & Lung & 1 & 0 & 1 & 0 & 0 \\
\hline Erlotinib [31] & TKIs & Lung & 9 & 6 & 6 & 19 & 0 \\
\hline Trastuzumab [86] & $\mathrm{mAb}$ & Breast & 0 & 2 & 5 & 7 & 0 \\
\hline
\end{tabular}

$39,56]$. The severity appears independent of concurrent chemotherapy but may be worse with monoclonal antibody therapy [57]. Interestingly, the presence of a skin rash has been associated with an improvement in response rate and survival [58]. Less commonly seen skin toxicity associated with EGFR-targeted therapy include: pruritus, dry skin, skin fissures, desquamation, and nail and cuticle cracking [59].

The mechanism by which EGFR blockade induces skin changes is incompletely understood. EGFR deficient mice have been found to have similar skin findings as patients treated with EGFR inhibitors [60]. Moreover EGFR skin toxicity appears dose dependent [61]. Molecular evaluation of EGFR treated epithelial cells have found an increase in apoptosis and enhanced expression of the negative growth signal p2 $7^{\mathrm{kip} 1}$ [58].

Diarrhea has been found in $39-55 \%$ of patients receiving Gefitinib or Erlotinib, although grade $\geq 3$ toxicity is infrequent and noted in $0-6 \%$ of patients $[2 \overline{8}, 31]$. Similarly, Grade 3-4 diarrhea is infrequently found in advanced colorectal cancer patients treated with Cetuximab monotherapy [56]. The mechanism by which EGFR induces diarrhea is unclear. Mice with reduced levels of enteric EGFR expression that undergo small bowel resection have slower intestinal adaptation and decreased levels of intestinal crypt cell proliferation when compared to mice with normal enteric EGFR expression suggesting a direct effect of EGFR blockade on the intestine [62].

Other toxicities associated with EGFR inhibition are infrequent, usually mild, and include: excessive eyelash growth, trichiasis, conjunctivitis, blepharitis, keratitis, and corneal erosion. Rare reports of interstitial lung disease, asymptomatic elevation in hepatic transaminases, and nephritic syndrome have been reported with small molecule tyrosine kinase inhibitors [28, 31, 59, 63].

Monoclonal antibody therapies, including Cetuximab and Trastuzumab, may trigger hypersensitivity reactions. They are however infrequent, occur during the first infusion and may not reappear with subsequent treatments $[49,56$, 64].

Trastuzumab's main side effect is cardiotoxicity. In metastatic breast cancer, severe cardiac toxicity occurs in about $3 \%$ of patients, although $50 \%$ of these patients have resolution after discontinuation of therapy [64]. In adjuvant breast cancer trials grade 3 or 4 congestive heart failure (CHF) occurred in $0.5 \%$ and $4.1 \%$ of patients treated with Trastuzumab, although symptoms resolved in $96 \%$ of these patients $[49,50]$. Risk factors for Trastuzumab associated cardiotoxicity include: age $>60$, concurrent use of anthracyclines, prior anthracycline use in excess of $\geq 400$ $\mathrm{mg} / \mathrm{m}^{2}$, prior chest irradiation, and prior cardiac dysfunction [64]. The underlying pathophysiology of Trastuzumab induced cardiac toxicity is unclear. Embryonic mice deficient in HER 2 receptors are aborted which may be the result of cardiac trabeculae dysfunction [65]. Interestingly, patients with radio-labeled cardiac uptake of Trastuzumab were found to have a high likelihood of exhibiting cardiac dysfunction while those without cardiac uptake were not [66].

\section{CLOSING REMARKS}

Due to the identification of some of the signaling pathways that promote cell growth and protect from cell death, targeted therapies became possible. Although the EGF-receptor family of molecules are just an example of a growing number of such pathways, their prevalence on epithelial malignancies (cancers) make them currently the most frequently therapeutically targeted specific pathways [1, 2 , 67]. Unfortunately, only a small subgroup of patients is sensitive to targeted therapies. There are various reasons for the shortcomings. For example, (i) tumors frequently overexpress membrane-bound complement regulatory proteins (mCRPs) on the cell surface. These regulators are protecting tumor cells from complement-mediated effector mechanisms. (ii) Sometimes tumors remain irresponsive due to the low expression of target molecules on tumor cells, e.g. HER2/neu. Furthermore, (iii) poor knowledge of cancer biology and interconnected signaling pathways that are either defective-, or hyper-activated in cancer may hamper efficient tumor cell death by targeted therapy due to multiple survival and resistance mechanisms. The blockage of mCRPs, composed of CD46, CD55 and CD59, appears to be one of the most promising approaches [68]. For example, tumor cell sensitization with rabbit polyclonal anti-tumor antiserum following mCRP neutralization, augmented cell lysis $10 \%-80 \%$ [68]. Another study shows that targeting multiple Her-2 epitopes with monoclonal antibodies results in improved anti-growth activity of a human breast cancer cell line in vitro and in vivo, in murine-SCID models [69]. As our knowledge on pathways responsible for the suppression of cell death and/or promotion of uncontrolled proliferation accumulates, similar pathway-directed therapies become developed for sarcomas, brain tumors, and other malignancies that are currently not effectively managed in the clinic [70, 71].

Monoclonal antibodies are currently in the focus of pharmaceutical companies because they offer a high degree of selectivity ("magic bullets"). Antibodies however have 
certain limitations that still need to be solved: So called "incomplete" antibodies, like those introduced in the first chapters of this review ( $a$ ) have short in-vivo half-lives, often they exhibit lower efficiency, and furthermore they do not always fix human complement or elicit ADCC with human mononuclear cells. Also, frequently $(b)$ they are not directed against growth receptors that are critical for cell survival and proliferation [72]. Conjugated antibodies in which drugs, toxins or radioactivity are attached to conventional monoclonal antibodies have been constructed, but only a few of them are currently used for cancer therapy $(c)$ due to side effects and often lower bio-stability. The side effects typically are a result of the type of substance that is attached to the particular antibody. Most importantly, unless 'humanized antibodies' are developed, $(d)$ the therapeutic antibodies elicit an immune response on their own and thus they are being removed by patient's immune system irrespectively of whether they are naked or conjugated. Furthermore, the immune reaction (e) results in the formation of immune complexes that can cause damage to the kidneys. Monoclonal antibodies raised in humans would lessen the problem; such technologies however, are currently at a rather experimental stage. This problem has been reduced to some extent by the use of genetic engineering to produce mouse-human hybrid antibodies (e.g. infliximab, rituximab, vitaxin etc.).

Furthermore, antibody's high molecular weight has also a profound effect on tumor targeting. IgG is a large protein complex itself $(\sim 150 \mathrm{kDa})$, thus it has slower distribution kinetics and severely limits tissue penetration as compared to small molecules. However, alteration of antibody structure can improve quantitative and selective tumor targeting [73]. This could be achieved by addition of specific peptides that for example allow intracellular penetration, or could assist crossing through the 'blood-brain-barrier' [74]. In spite of the above-mentioned difficulties, at least 18 monoclonal antibodies have been approved by the Food and Drug Administration (FDA), while many are still in clinical trials. It is expected that as we learn how to improve the pharmacokinetic properties of antibodies and how to diminish their adverse interactions with the immune system, monoclonal antibodies will gain importance as therapeutic molecules, either alone or in combination with the "classical" cancer radio- and chemotherapy.

As our knowledge on cancer patho-biology expands, it is plausible to predict that at least in some cases, monoclonal antibodies will eventually be eliminated from the clinic in favor of biologically active peptides, peptidomimetics, 'small molecule' inhibitors, or perhaps even by the classical cancer immuno-therapy [75, 76]. For example Pertuzumab's dimerization-inhibitory activity (inhibits HER dimerization), will certainly one day be achieved by small molecules or at least peptidomimetics. As such molecules are much smaller than antibodies, they will likely have better bioavailability and pharmacokinetics, especially within the tumor's microenvironment.

Antibodies are however not the only means to "selectively hit" cancer cells. Several molecules have been described that are more or less specifically toxic towards transformed cells. Our knowledge is currently most advanced on the cancer selective mechanism of action of a viral protein called apoptin [77]. But beside apoptin, a number of other molecules have been described to have cancer-selective mechanism of action, for example: E4orf4, S100A8/A9, viral protein $\mathrm{R}(\mathrm{VpR})$, and Brevinin-2R [78, 79]. In addition to approaches that selectively target cancer cells, significant therapy improvement could also be achieved by better monitoring of cancer therapy-induced cell death (therapy efficacy) and thus by more accurate chemotherapy dosage. One of the most promising molecules that indicate on going in vivo apoptosis, is the serum level of cytochrome c, a small mitochondrial protein, that is selectively released from mitochondria, and also from dying cells upon apoptosis induction [80-82]. These approaches can further be combined with substances that sensitize cancer cells to standard chemotherapies, either non-selectively, or selectively, in order to achieve desired chemotherapy effect [83, 84].

\section{ACKNOWLEDGEMENTS}

G.S is currently funded by a Postdoctoral Fellowship from the Manitoba Health Research Council (MHRC) and previously from the CancerCare Manitoba Foundation (CCMF). M.L. thankfully acknowledges the support by the Canada Research Chair program, PCRFC-, MMSF-, CCMF-, MHRC-, and CIHR -financed programs. L.C.M. acknowledges the support of the Canadian Breast Cancer Research Alliance (CBCRA) and CIHR. We acknowledge the strong support of the CCMF for our facilities at MICB.

$\begin{array}{ll}\text { ABBREVIATIONS } \\ \text { ADCC } \\ \text { B-ALL } & =\begin{array}{l}\text { Antibody Dependent Cellular Cytotoxicity } \\ \text { hoblastic leukemia }\end{array} \\ \text { CDC } & =\text { Complement-mediated Cytotoxicity } \\ \text { CML } & =\text { Chronic myeloid leukemia } \\ \text { EGF } & =\text { Epideremal Growth Factor } \\ \text { EGFR } & =\text { Epideremal Growth Factor Receptor } \\ \text { HB-EGF } & =\text { Heparin-Binding Epidermal Growth } \\ \text { IL } & =\text { Interleukin } \\ \text { OS } & =\text { Overall Survival } \\ \text { mAbs } & =\text { Monoclonal Antibodies } \\ \text { NSCLC } & =\text { Non Small Cell Lung Cancer } \\ \text { PI-3K } & =\text { Phosphatidyloinositol 3-Kinase } \\ \text { TKI } & =\text { Tyrosine kinase } \\ \text { TK } & =\text { Tyrosine Kinase Inhibitors } \\ \text { VEGF } & =\text { Vascular Endothelial Growth Factor }\end{array}$

\section{LITERATURE}

[1] Brown, J.G.; Gibson, S.B.; (2005). Growth Factors, Receptors, and Kinases: their Exploration to Target Cancer. In Apoptotic pathways as target for novel therapies in cancer and other 
diseases, Los, M.; Gibson, S.B., eds. (Springer Science+Business Media, Inc.), pp. 173-196.

[2] Booy, E.P.; Johar, D.; Maddika, S.; Pirzada, H.; Sahib, M.M.; Gehrke, I.; Loewen, S.D.; Louis, S.D.; Kadkhoda, K.; Mowat, M.; Los, M. Arch. Immunol. Ther. Exp., 2006, 54, 1-17.

[3] Kohler, G.; Milstein, C. Nature, 1975, 256, 495-497.

[4] White, C.A.; Weaver, R.L.; Grillo-Lopez, A.J. Annu. Rev. Med., 2001, 52, 125-145.

[5] Hong, F.; Hansen, R.D.; Yan, J.; Allendorf, D.J.; Baran, J.T.; Ostroff, G.R.; Ross, G.D. Cancer Res., 2003, 63, 9023-9031.

[6] Kortt, A.A.; Dolezal, O.; Power, B.E.; Hudson, P.J. Biomol. Eng., 2001, 18, 95-108.

[7] Carter, P. Nat. Rev. Cancer., 2001, 1, 118-129.

[8] Park, J.W.; Hong, K.; Kirpotin, D.B.; Colbern, G.; Shalaby, R.; Baselga, J.; Shao, Y.; Nielsen, U.B.; Marks, J.D.; Moore, D.; Papahadjopoulos, D.; Benz, C.C. Clin. Cancer Res., 2002, 8, 1172 1181.

[9] Giles, F.; Estey, E.; O'Brien, S. Cancer, 2003, 98, 2095-2104.

[10] Yovtchev, Y.; Nilolov, S. Radiol. Oncol, 2001, 35, 111-115.

[11] Robinson, M.K.; Weiner, L.M.; Adams, G.P. Drug Development Research, 2004, 61, 172-187.

[12] Ross, J.S.; Schenkein, D.P.; Pietrusko, R.; Rolfe, M.; Linette, G.P.; Stec, J.; Stagliano, N.E.; Ginsburg, G.S.; Symmans, W.F.; Pusztai, L.; Hortobagyi, G.N. Am. J. Clin. Pathol., 2004, 122, 598-609.

[13] Buhring, H.J.; Sures, I.; Jallal, B.; Weiss, F.U.; Busch, F.W.; Ludwig, W.D.; Handgretinger, R.; Waller, H.D.; Ullrich, A. Blood, 1995, 86, 1916-1923.

[14] Chevallier, P.; Robillard, N.; Wuilleme-Toumi, S.; Mechinaud, F.; Harousseau, J.L.; Avet-Loiseau, H. Haematologica, 2004, 89, 1399-1401.

[15] Muller, M.R.; Grunebach, F.; Kayser, K.; Vogel, W.; Nencioni, A.; Brugger, W.; Kanz, L.; Brossart, P. Clin. Cancer Res., 2003, 9 , 3448-3453.

[16] Bairey, O.; Pazgal, I.; Okon, E.; Shaklai, M.; Morgenshtern, S. Arch. Pathol. Lab. Med., 2002, 126, 574-576.

[17] Luftner, D.; Genvresse, I.; Geppert, R.; Kaufmann, O.; Dietel, M.; Possinger, K. Anticancer Res., 2004, 24, 3233-3237.

[18] Su, I.J.; Kadin, M.E. Am. J. Pathol., 1989, 135, 439-445.

[19] Stegmaier, K.; Corsello, S.M.; Ross, K.N.; Wong, J.S.; Deangelo, D.J.; Golub, T.R. Blood, 2005, 106, 2841-2848.

[20] De Vos, J.; Couderc, G.; Tarte, K.; Jourdan, M.; Requirand, G.; Delteil, M.C.; Rossi, J.F.; Mechti, N.; Klein, B. Blood, 2001, 98, 771-780.

[21] Wang, Y.D.; De Vos, J.; Jourdan, M.; Couderc, G.; Lu, Z.Y.; Rossi, J.F.; Klein, B. Oncogene, 2002, 21, 2584-2592.

[22] Otsuki, T.; Kurebayashi, J.; Ohkubo, S.; Uno, M.; Fujii, T.; Sakaguchi, H.; Hatayama, T.; Takata, A.; Tsujioka, T.; Sugihara, T.; Hyodoh, F. Int. J. Oncol., 2003, 23, 1135-1141.

[23] Mahtouk, K.; Hose, D.; Reme, T.; De Vos, J.; Jourdan, M.; Moreaux, J.; Fiol, G.; Raab, M.; Jourdan, E.; Grau, V.; Moos, M.; Goldschmidt, H.; Baudard, M.; Rossi, J.F.; Cremer, F.W.; Klein, B. Oncogene, 2005, 24, 3512-3524.

[24] Mahtouk, K.; Jourdan, M.; De Vos, J.; Hertogh, C.; Fiol, G.; Jourdan, E.; Rossi, J.F.; Klein, B. Blood, 2004, 103, 1829-1837.

[25] Nguyen, D.M.; Schrump, D.S. Semin. Thorac. Cardiovasc. Surg., 2004, 16, 3-12.

[26] Selvaggi, G.; Novello, S.; Torri, V.; Leonardo, E.; De Giuli, P.; Borasio, P.; Mossetti, C.; Ardissone, F.; Lausi, P.; Scagliotti, G.V. Ann. Oncol., 2004, 15, 28-32.

[27] Onn, A.; Isobe, T.; Wu, W.; Itasaka, S.; Shintani, T.; Shibuya, K.; Kenji, Y.; O'Reilly M, S.; Fidler, I.J.; Herbst, R.S. Clin. Cancer Res., 2004, 10, 8613-8619.

[28] Fukuoka, M.; Yano, S.; Giaccone, G.; Tamura, T.; Nakagawa, K.; Douillard, J.Y.; Nishiwaki, Y.; Vansteenkiste, J.; Kudoh, S.; Rischin, D.; Eek, R.; Horai, T.; Noda, K.; Takata, I.; Smit, E.; Averbuch, S.; Macleod, A.; Feyereislova, A.; Dong, R.P.; Baselga, J. J Clin. Oncol., 2003, 21, 2237-2246.

[29] Kris, M.G.; Natale, R.B.; Herbst, R.S.; Lynch, T.J., Jr.; Prager, D.; Belani, C.P.; Schiller, J.H.; Kelly, K.; Spiridonidis, H.; Sandler, A.; Albain, K.S.; Cella, D.; Wolf, M.K.; Averbuch, S.D.; Ochs, J.J.; Kay, A.C. Jama., 2003, 290, 2149-2158.

[30] Thatcher, N.; Chang, A.; Parikh, P.; Rodrigues Pereira, J.; Ciuleanu, T.; von Pawel, J.; Thongprasert, S.; Tan, E.H.; Pemberton, K.; Archer, V.; Carroll, K. Lancet, 2005, 366, 1527 1537.

[31] Shepherd, F.A.; Rodrigues Pereira, J.; Ciuleanu, T.; Tan, E.H.; Hirsh, V.; Thongprasert, S.; Campos, D.; Maoleekoonpiroj, S.;
Smylie, M.; Martins, R.; van Kooten, M.; Dediu, M.; Findlay, B.; Tu, D.; Johnston, D.; Bezjak, A.; Clark, G.; Santabarbara, P.; Seymour, L. N. Engl. J Med., 2005, 353, 123-132.

[32] Lynch, T.J. Clin. Adv. Hematol. Oncol., 2004, 2, 786-787.

[33] Paez, J.G.; Janne, P.A.; Lee, J.C.; Tracy, S.; Greulich, H.; Gabriel, S.; Herman, P.; Kaye, F.J.; Lindeman, N.; Boggon, T.J.; Naoki, K.; Sasaki, H.; Fujii, Y.; Eck, M.J.; Sellers, W.R.; Johnson, B.E.; Meyerson, M. Science, 2004, 304, 1497-1500.

[34] Cappuzzo, F.; Finocchiaro, G.; Trisolini, R.; Toschi, L.; Bartolini, S.; Metro, G.; Crino, L. Oncology (Williston Park), 2005, 19, 989 995; discussion 995-986, 999, 1003-1004, passim.

[35] Tsao, M.S.; Sakurada, A.; Cutz, J.C.; Zhu, C.Q.; Kamel-Reid, S.; Squire, J.; Lorimer, I.; Zhang, T.; Liu, N.; Daneshmand, M.; Marrano, P.; da Cunha Santos, G.; Lagarde, A.; Richardson, F.; Seymour, L.; Whitehead, M.; Ding, K.; Pater, J.; Shepherd, F.A. N. Engl. J. Med., 2005, 353, 133-144.

[36] Giaccone, G.; Herbst, R.S.; Manegold, C.; Scagliotti, G.; Rosell, R.; Miller, V.; Natale, R.B.; Schiller, J.H.; Von Pawel, J.; Pluzanska, A.; Gatzemeier, U.; Grous, J.; Ochs, J.S.; Averbuch, S.D.; Wolf, M.K.; Rennie, P.; Fandi, A.; Johnson, D.H. J. Clin. Oncol., 2004, 22, 777-784.

[37] Herbst, R.S.; Giaccone, G.; Schiller, J.H.; Natale, R.B.; Miller, V.; Manegold, C.; Scagliotti, G.; Rosell, R.; Oliff, I.; Reeves, J.A.; Wolf, M.K.; Krebs, A.D.; Averbuch, S.D.; Ochs, J.S.; Grous, J.; Fandi, A.; Johnson, D.H. J. Clin. Oncol., 2004, 22, 785-794.

[38] Huang, C.L.; Yokomise, H.; Fukushima, M.; Kinoshita, M. Future Oncol., 2006, 2, 289-299.

[39] Herbst, R.S.; Prager, D.; Hermann, R.; Fehrenbacher, L.; Johnson, B.E.; Sandler, A.; Kris, M.G.; Tran, H.T.; Klein, P.; Li, X.; Ramies, D.; Johnson, D.H.; Miller, V.A. J. Clin. Oncol., 2005, 23, 5892-5899.

[40] Dubey, S.; Schiller, J.H. Oncologist, 2005, 10, 282-291.

[41] Temel, J.S.; Pirl, W.F.; Lynch, T.J. Clin. Lung Cancer, 2006, 7, 241-249.

[42] Robert, F.; Blumenschein, G.; Herbst, R.S.; Fossella, F.V.; Tseng, J.; Saleh, M.N.; Needle, M. J. Clin. Oncol., 2005, 23, 9089-9096.

[43] Thienelt, C.D.; Bunn, P.A., Jr.; Hanna, N.; Rosenberg, A.; Needle, M.N.; Long, M.E.; Gustafson, D.L.; Kelly, K. J. Clin. Oncol., 2005, 23, 8786-8793.

[44] Polychronis, A.; Sinnett, H.D.; Hadjiminas, D.; Singhal, H.; Mansi, J.L.; Shivapatham, D.; Shousha, S.; Jiang, J.; Peston, D.; Barrett, N.; Vigushin, D.; Morrison, K.; Beresford, E.; Ali, S.; Slade, M.J.; Coombes, R.C. Lancet Oncol., 2005, 6, 383-391.

[45] Baselga, J.; Albanell, J.; Ruiz, A.; Lluch, A.; Gascon, P.; Guillem, V.; Gonzalez, S.; Sauleda, S.; Marimon, I.; Tabernero, J.M.; Koehler, M.T.; Rojo, F. J. Clin. Oncol., 2005, 23, 5323-5333.

[46] von Mehren, M.; Adams, G.P.; Weiner, L.M. Annu. Rev. Med., 2003, 54, 343-369.

[47] Burris, H.A., 3rd; Hurwitz, H.I.; Dees, E.C.; Dowlati, A.; Blackwell, K.L.; O'Neil, B.; Marcom, P.K.; Ellis, M.J.; Overmoyer, B.; Jones, S.F.; Harris, J.L.; Smith, D.A.; Koch, K.M.; Stead, A.; Mangum, S.; Spector, N.L. J. Clin. Oncol., 2005, 23, 5305-5313.

[48] Slamon, D.J.; Leyland-Jones, B.; Shak, S.; Fuchs, H.; Paton, V.; Bajamonde, A.; Fleming, T.; Eiermann, W.; Wolter, J.; Pegram, M.; Baselga, J.; Norton, L. N. Engl. J. Med., 2001, 344, 783-792.

[49] Piccart-Gebhart, M.J.; Procter, M.; Leyland-Jones, B.; Goldhirsch, A.; Untch, M.; Smith, I.; Gianni, L.; Baselga, J.; Bell, R.; Jackisch, C.; Cameron, D.; Dowsett, M.; Barrios, C.H.; Steger, G.; Huang, C.S.; Andersson, M.; Inbar, M.; Lichinitser, M.; Lang, I.; Nitz, U.; Iwata, H.; Thomssen, C.; Lohrisch, C.; Suter, T.M.; Ruschoff, J.; Suto, T.; Greatorex, V.; Ward, C.; Straehle, C.; McFadden, E.; Dolci, M.S.; Gelber, R.D. N. Engl. J. Med., 2005, 353, 1659-1672.

[50] Romond, E.H.; Perez, E.A.; Bryant, J.; Suman, V.J.; Geyer, C.E., Jr.; Davidson, N.E.; Tan-Chiu, E.; Martino, S.; Paik, S.; Kaufman, P.A.; Swain, S.M.; Pisansky, T.M.; Fehrenbacher, L.; Kutteh, L.A.; Vogel, V.G.; Visscher, D.W.; Yothers, G.; Jenkins, R.B.; Brown, A.M.; Dakhil, S.R.; Mamounas, E.P.; Lingle, W.L.; Klein, P.M.; Ingle, J.N.; Wolmark, N. N. Engl. J. Med., 2005, 353, 1673-1684.

[51] Buzdar, A.U.; Ibrahim, N.K.; Francis, D.; Booser, D.J.; Thomas, E.S.; Theriault, R.L.; Pusztai, L.; Green, M.C.; Arun, B.K.; Giordano, S.H.; Cristofanilli, M.; Frye, D.K.; Smith, T.L.; Hunt, K.K.; Singletary, S.E.; Sahin, A.A.; Ewer, M.S.; Buchholz, T.A.; Berry, D.; Hortobagyi, G.N. J. Clin. Oncol., 2005, 23, 3676-3685.

[52] Marty, M.; Cognetti, F.; Maraninchi, D.; Snyder, R.; Mauriac, L.; Tubiana-Hulin, M.; Chan, S.; Grimes, D.; Anton, A.; Lluch, A.; 
Kennedy, J.; O'Byrne, K.; Conte, P.; Green, M.; Ward, C.; Mayne, K.; Extra, J.M. J. Clin. Oncol., 2005, 23, 4265-4274.

[53] Agus, D.B.; Gordon, M.S.; Taylor, C.; Natale, R.B.; Karlan, B.; Mendelson, D.S.; Press, M.F.; Allison, D.E.; Sliwkowski, M.X.; Lieberman, G.; Kelsey, S.M.; Fyfe, G. J. Clin. Oncol., 2005, 23, 2534-2543.

[54] Miller, K.D.; Trigo, J.M.; Wheeler, C.; Barge, A.; Rowbottom, J.; Sledge, G.; Baselga, J. Clin. Cancer Res., 2005, 11, 3369-3376.

[55] Thomas, M. Clin. J. Oncol. Nurs., 2005, 9, 332-338.

[56] Cunningham, D.; Humblet, Y.; Siena, S.; Khayat, D.; Bleiberg, H.; Santoro, A.; Bets, D.; Mueser, M.; Harstrick, A.; Verslype, C.; Chau, I.; Van Cutsem, E. N. Engl. J. Med., 2004, 351, 337-345.

[57] Jacot, W.; Bessis, D.; Jorda, E.; Ychou, M.; Fabbro, M.; Pujol, J.L.; Guillot, B. Br. J. Dermatol., 2004, 151, 238-241.

[58] Segaert, S.; Tabernero, J.; Chosidow, O.; Dirschka, T.; Elsner, J.; Mancini, L.; Maughan, T.; Morere, J.F.; Santoro, A.; Sobrero, A.; Van Cutsem, E.; Layton, A. J. Dtsch. Dermatol. Ges., 2005, 3, 599-606.

[59] Shah, N.T.; Kris, M.G.; Pao, W.; Tyson, L.B.; Pizzo, B.M.; Heinemann, M.H.; Ben-Porat, L.; Sachs, D.L.; Heelan, R.T.; Miller, V.A. J. Clin. Oncol., 2005, 23, 165-174.

[60] Segaert, S.; Van Cutsem, E. Ann. Oncol., 2005, 16, 1425-1433.

[61] Ng, M.; Cunningham, D. Int. J. Clin. Pract., 2004, 58, 970-976.

[62] Helmrath, M.A.; Erwin, C.R.; Warner, B.W. J. Surg. Res., 1997, 69, 76-80.

[63] Kumasaka, R.; Nakamura, N.; Shirato, K.; Osawa, H.; Takanashi, S.; Hasegawa, Y.; Yamabe, H.; Nakamura, M.; Tamura, M.; Okumura, K. J. Clin.. Oncol., 2004, 22, 2504-2505.

[64] Horton, J. Cancer Control, 2002, 9, 499-507.

[65] Lee, K.F.; Simon, H.; Chen, H.; Bates, B.; Hung, M.C.; Hauser, C. Nature, 1995, 378, 394-398.

[66] Behr, T.M.; Behe, M.; Wormann, B. N. Engl. J. Med., 2001, 345, 995-996.

[67] Krzemieniecki, K.; Szpyt, E.; Rashedi, I.; Gawron, K.; Los, M. Centr. Eur. J. Biol., 2006, 1, 167-182.

[68] Jurianz, K.; Maslak, S.; Garcia-Schuler, H.; Fishelson, Z.; Kirschfink, M. Immunopharmacology, 1999, 42, 209-218.

[69] Spiridon, C.I.; Ghetie, M.A.; Uhr, J.; Marches, R.; Li, J.L.; Shen, G.L.; Vitetta, E.S. Clin. Cancer Res., 2002, 8, 1720-1730

[70] Kroczak, T.J.; Baran, J.; Pryjma, J.S., M.; Rashedi, I.; Hernandez, E.; Alberti, E.M., S.; Los, M. Expert Opin. Ther. Targets, 2006, 10, 289-302.
[71] Philchenkov, A.; Zavelevich, M.; Kroczak, T.J.; Los, M. Exp. Oncol., 2004, 26, 82-97.

[72] Waldmann, T.A. Nat Med, 2003, 9, 269-277.

[73] Weiner, L.M.; Adams, G.P. Oncogene, 2000, 19, 6144-6151.

[74] Hauff, K.; Zamzow, C.; Law, W.J.; de Melo, J.; Kennedy, K.; Los, M. Arch. Immunol. Ther. Exp., 2005, 53, 308-320.

[75] Booy, E.P.; Kadkhoda, K.; Johar, D.; Bay, G.H.; Los, M. Curr. Med. Chem.-Anti-Inflammatory \& Anti-Allergy Agents, 2005, 4, 349-353.

[76] Mendoza, F.J.; Espino, P.S.; Cann, K.L.; Bristow, N.; McCrea, K.; Los, M. Arch. Immunol. Ther. Exp., 2005, 53, 47-60.

[77] Maddika, S.; Booy, E.P.; Johar, D.; Gibson, S.B.; Ghavami, S.; Los, M. J. Cell Sci., 2005, 118, 4485-4493.

[78] Ghavami, S.; Kerkhoff, C.; Los, M.; Hashemi, M.; Sorg, C.; Karami-Tehrani, F. J. Leukoc. Biol., 2004, 76, 169-175.

[79] Maddika, S.; Mendoza, F.J.; Hauff, K.; Zamzow, C.R.; Paranjothy, T.; Los, M. Cancer Biol. Ther., 2006, 5, 10-19.

[80] Ghavami, S.; Barczyk, K.; Maddika, S.; Vogl, T.; Steinmüller, L.; Pour- Jafari, H.; Evans, J.A.; Los, M.; (2005). Monitoring of programmed cell death in vivo and in vitro, -new and old methods of cancer therapy assessment. In Apoptotic pathways as target for novel therapies in cancer and other diseases, Los, M.; Gibson, S.B., eds. (New York: Springer Science+Business Media, Inc.), pp. 323-341.

[81] Barczyk, K.; Kreuter, M.; Pryjma, J.; Booy, E.P.; Maddika, S.; Ghavami, S.; Berdel, W.E.; Roth, J.; Los, M. Int. J. Cancer, 2005 , $114,167-173$.

[82] Ghavami, S.; Hashemi, M.; Kadkhoda, K.; Alavian, S.M.; Bay, G.H.; Los, M. Med. Sci. Monitor, 2005, 11, in press.

[83] Hashemi, M.; Karami-Tehrani, F.; Ghavami, S.; Maddika, S.; Los, M. Cell Proliferat., 2005, 38, 269-285.

[84] Kreuter, M.; Langer, C.; Kerkhoff, C.; Reddanna, P.; Kania, A.L.; Maddika, S.; Chlichlia, K.; Bui, T.N.; Los, M. Arch. Immunol. Ther. Exp., 2004, 52, 141-155.

[85] von Minckwitz, G.; Jonat, W.; Fasching, P.; du Bois, A.; Kleeberg, U.; Luck, H.J.; Kettner, E.; Hilfrich, J.; Eiermann, W.; Torode, J.; Schneeweiss, A. Breast Cancer Res Treat, 2005, 89, 165-172.

[86] Vogel, C.L.; Cobleigh, M.A.; Tripathy, D.; Gutheil, J.C.; Harris, L.N.; Fehrenbacher, L.; Slamon, D.J.; Murphy, M.; Novotny, W.F.; Burchmore, M.; Shak, S.; Stewart, S.J.; Press, M. J. Clin. Oncol., 2002, 20, 719-726. 